\title{
LONG-TERM RESPONSE OF SMALL MAMMAL COMMUNITIES TO THE 1988 HUCKLEBERRY MOUNTAIN FIRE
}

\section{SCOTT BURT $\uparrow$ R. SCOTT SEVILLE $\uparrow$ WAYNE CUMMINGS $\uparrow$ REBECCA ZOOK UNIVERSITY OF WYOMING $\uparrow$ CASPER}

\begin{abstract}
$\uparrow \quad$ AbSTRACT
Biologists have long been interested in the response of small mammals and their habitat following natural disturbances. The Greater Yellowstone Area (GYA) fires of 1988 have provided opportunities to study short and long term responses. This study continues investigations conducted in the 1990's following identical methodology at the same sites now 21 years post-fire. We live trapped 256 Clethrionomys gapperi (Red-backed Vole), 116 Peromyscus maniculatus (Deer Mouse), 44 Tamius minimus (Least Chipmunk), 28 Zapus princeps (Western Jumping Mouse), two Microtus montanus (Montane Vole), 1 Thomomys talpoides (Northern Pocket Gopher) and 37 shrews (Sorex ssp.). These results support findings from other investigations regarding the initial early dominance of $P$. maniculatus in burn areas and $C$. gapperi in control or non-burn areas, and as time has progressed since the burn, differences between burn and control sites (as measured by community diversity indices) has decreased. As expected calculated Shannon diversity indices (H') in 2009 are higher for at least one of the burn sites than in previous years as the habitat recovers to pre-burn conditions.
\end{abstract}

\section{$\uparrow \quad$ INTRODUCTION}

Biologists have long wondered about the role of disturbance in shaping communities, but few studies have looked at long term responses following natural disturbances such as fire. Most have looked at shorter time frames (ten years or less), made comparisons among different sites, or investigated the role of manmade disturbances (e.g., prescribed burning). Few studies have specifically investigated the short and long term changes in small mammal communities (rodents and shrews) in response to natural forest fires, but trends and patterns have emerged from previous work. An excellent review of this growing body of literature for boreal forests is provided by Fisher and Wilkinson (2005). In the early stages (0-10 years) of recovery post-fire, defined as the initiation stage (Lee 2002), small mammal responses are variable and often include changes in relative abundance within the community rather than outright species replacements over time. The generalist deer mouse (Peromyscus maniculatus) typically responds positively in the years following fire and is often the most numerically dominant species. Data for the southern red-backed vole (Clethrionomys gapperi) are sometimes conflicting, though most suggest rapid recolonization post-fire even though the species is believed to be an old-growth specialist. Given that grasses are common in the years immediately following fires, the presence of grassland species such as meadow voles (Microtus pennsylvanicus) and meadow jumping mice (Zapus hudsonius) is not surprising.

Less is known regarding the response of insectivores to fire disturbances. Since they feed on invertebrates, correlative responses to habitat change are less predictable as is the case with granivores and folivores (Kirkland and Parmenter 1977). None the less, the loss of ground cover (leaf litter, e.g.) and a shift to a more xeric microhabitat is likely to adversely affect the shrew community in the initiation stage. 
The extensive 1988 fires of the GYA have provided biologists with an opportunity to study the short and long term effects of a natural disturbance on small mammals and of the correlative or causative relationships between successional stages of the vegetative community and small mammal community structure. Previous studies by Stanton et al. (1991), Spildie (1994), and Seville et al.(1998) at Huckleberry Mountain, Wyoming have investigated small mammal communities and habitat structure in both burned and unburned grids at 3, 4, 6, 9, 10 and 21 years post-fire near Huckleberry Mountain in Grand Teton National Park. We wish to continue the previous work and investigate not only the microhabitat structure, but ultimately relationships between habitat change and small mammal community structure following another season of collection in 2010. In 2009 we focused on small mammal community structure in burned and unburned grids, and microhabitat structure in the immediate vicinity of randomly selected trap stations. Given Taylor's (1973) assertion that diversity is highest 25 years post-fire, the time has come to revisit the sites at Huckleberry Mountain and investigate the small mammal communities and the corresponding changes in habitat structure.

This study investigates the structure of small mammal communities and the habitat in both burned and unburned grids 21 years after the fire. Our specific objectives are to:

1. Determine the composition of small mammal communities 22 years post-fire in burned and adjacent unburned grids using identical locations and methodologies of previous investigations.

2. Collect habitat structure data from burned and unburned grids following similar sampling protocol from previous investigations.

3. Compare the community structure of small mammals from this study with previous investigations from Huckleberry Mountain.

\section{$\uparrow \quad$ METHODS}

Trap effort (number of traps/grid, trap nights, and location) followed exactly the protocol from previous work at these locations. For one week during June, July, and August 2009 we sampled the identical burned (2) and unburned (2) 1 hectare trapping grids on Huckleberry Mountain studied by Stanton et al. (1991,1992), and Seville et al. (1998). All grids are located in Teton County Wyoming, Grand Teton National Park, 10.5 north of the junction with Leeks
Marina road along highway 287. Specific UTM coordinates for each grid (all in zone 12) are: east facing burn 0525026, 4877860; east facing control 0524534, 4877666; west facing burn 0525026, 4877410; west facing control 0525020, 4877386.

During each 4-day trapping period at each grid, 100 Sherman traps were placed (100 stations/ha, $10 \mathrm{~m}$ apart) and baited with rolled oats and peanut butter. Traps were opened between 1530 and 1730 and checked between 0500 and 0830 the following day. Cotton batting was placed in each trap for insulation/nest construction. Pitfall traps were placed at every fourth trap station (25pitfalls/grid) to capture insectivores. Captured animals were uniquely ear tagged and classified by species, sex, age class (juvenile or adult) and reproductive condition, weighed to the nearest gram and released where caught. Animals and traps were handled in accordance with current USFS employee guidelines for handling small rodents with the potential to transmit hantavirus. All field investigators wore HEPA half-mask respirators. At the end of each trapping session, all traps were cleaned with a $10 \%$ bleach solution.

Habitat data were collected from 80 randomly selected trap stations (20/grid). Data gathered at each trap station included distance to nearest tree (within $5 \mathrm{~m}$ of trap station), diameter at breast height for tree, distance to nearest sapling (within $5 \mathrm{~m}$ of trap station), diameter at breast height for sapling, distance to nearest seedling (within $5 \mathrm{~m}$ ), distance to nearest shrub (with $5 \mathrm{~m}$ ), percent ground cover (in a 1 square meter area) for grass, herbaceous, leaf litter, bare ground, coarse woody debris, and logs. In addition, a $5 \mathrm{~m}$ tape was placed down in the four cardinal directions $(\mathrm{N}, \mathrm{S}$, $\mathrm{E}, \mathrm{W})$, and at any point coarse woody debris crosses the tape, distance was measured from the trap station and the diameter of the woody debris obtained. Diversity within sites was estimated using the Shannon-Wiener Index $\left(\mathrm{H}^{\prime}=-\sum p_{i} \log p_{i}\right)$ and compared with indices from previous years.

\section{$\uparrow \quad$ RESULTS}

Ten species of mammals and 485 individuals were captured in 2009, including 256 C. gapperi, 116 P. maniculatus, 44 Tamias minimus, 28 Zapus princeps, 9 Sorex cinereus, 8 S. monticolus, 2 Microtus montanus, 1 Tamiasciurus hudsonicus, 1 S. merriami, and 1 Thomomys talpoides. Nineteen Sorex have not yet been identified to species. Total numbers of species by grid are provided in Table 1. 
Table 1. Total number of each species captured per grid in 2009. EFB: east facing burn, EFC: east facing control, WFB: west facing burn, WFC: west facing control.

\begin{tabular}{|l|c|c|c|c|c|}
\hline & EFB & EFC & WFB & WFC & Total \\
\hline $\begin{array}{l}\text { Clethrionomys } \\
\text { gapperi }\end{array}$ & 31 & 58 & 54 & 113 & 256 \\
\hline $\begin{array}{l}\text { Microtus } \\
\text { montanus }\end{array}$ & 0 & 1 & 1 & 0 & 2 \\
\hline $\begin{array}{l}\text { Peromyscus } \\
\text { maniculatus }\end{array}$ & 50 & 32 & 22 & 12 & 116 \\
\hline $\begin{array}{l}\text { Sorex } \\
\text { cinereus }\end{array}$ & 2 & 3 & 0 & 4 & 9 \\
\hline $\begin{array}{l}\text { S. monticouls } \\
\text { S. merriami }\end{array}$ & 4 & 3 & 0 & 1 & 8 \\
\hline Sorex spp. & 7 & 7 & 4 & 1 & 19 \\
\hline $\begin{array}{l}\text { Thomomys } \\
\text { talpoides }\end{array}$ & 0 & 0 & 0 & 1 & 1 \\
\hline $\begin{array}{l}\text { Tamiasciurus } \\
\text { hudsonicus }\end{array}$ & 0 & 0 & 1 & 0 & 1 \\
\hline $\begin{array}{l}\text { Tamias } \\
\text { minimus }\end{array}$ & 9 & 10 & 16 & 9 & 44 \\
\hline $\begin{array}{l}\text { Zapus } \\
\text { princeps }\end{array}$ & 9 & 3 & 0 & 16 & 28 \\
\hline & 112 & 118 & 98 & 157 & $\mathbf{4 8 5}$ \\
\hline
\end{tabular}

The east facing grids harbored more diverse small mammal communities than the west facing grids, and in the respective east/west facing slopes, community structure was similar. Shannon-Wiener diversity indices for the 2009 season are as follows: east facing burn: 0.60509; east facing control: 0.57142; west facing burn: 0.49662 ; west facing control: 0.43459 .

Extensive amounts of habitat data were collected, and final analyses investigating relationships between small mammals and habitat structure will not be performed until a second year of data are collected in 2010, but basic summaries of select habitat features typical of each grid and likely important to small mammals are included in this report. Informal comparisons of percent cover for herbaceous cover, grass cover, and litter cover for each grid are shown in Figures 1-3 respectively. Herbaceous cover is relatively greater in control girds, grass cover is greater in burned grids, and leaf litter is similar among all grids regardless of burn/control. Burn grids also have fewer and smaller trees and larger diameter saplings than control grids (Table 2). Comparisons of proportions of small
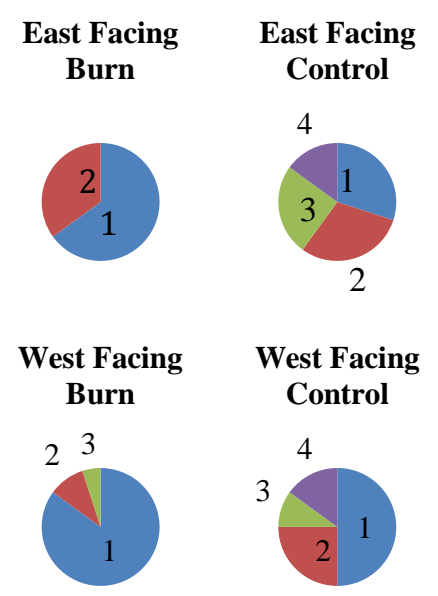

Figure 1. Herbaceous cover classes on the 4 grids during the summer of 2009 . 1: $0-25 \%$ cover; $2: 26-50 \%$ cover; $3: 51-75 \%$ cover; 4: 76-100\% cover.

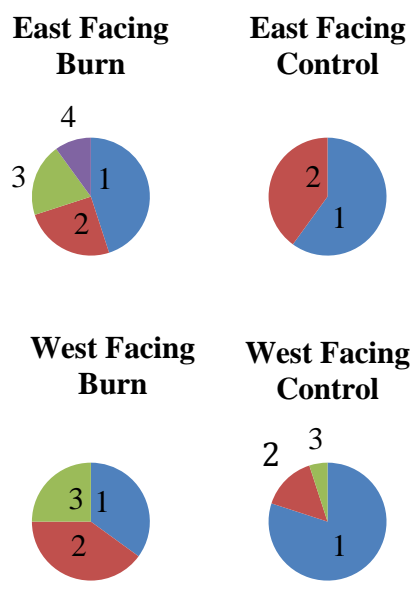

Figure 2. Grass cover classes on the 4 grids during the summer of 2009. See Figure 1 for a description of cover classes.
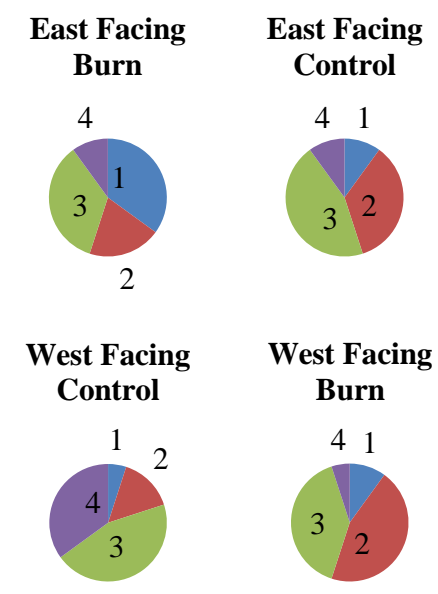

Figure 3. Litter cover classes on the 4 grids during the summer of 2009. See Figure 1 for a description of cover classes. 
mammals by grids for the 1997, 1998 and 2009 seasons are illustrated in Figure 4-7. Clethrionomys gapperi dominates the communities in both control grids. Peromyscus maniculatus dominates the community in the east facing burn, but not in the west facing burn relative to $C$. gapperi. Also, as time progresses, the number of rare species (e.g., Tamias minimus) increases in the burn grids. No species breakdown for shrews is available for the 1998 field season, so for these comparisons, all shrews are lumped into Sorex sp.

Table 2. Comparison of prevalence of trees, including $\mathrm{DBH}$, among the four grids. See Table 1 for abbreviations.

\begin{tabular}{|l|c|c|c|c|}
\hline & EFB & EFC & WFB & WFC \\
\hline $\begin{array}{l}\text { Percent sites with trees } \\
(\text { DBH }>10 \mathrm{~cm})\end{array}$ & 15 & 95 & 0 & 100 \\
\hline Mean tree DBH (cm) & 11 & 21.68 & na & 22.95 \\
\hline $\begin{array}{l}\text { Mean sapling DBH } \\
(\mathrm{cm})\end{array}$ & 5.94 & 4.05 & 5.1 & 3.16 \\
\hline
\end{tabular}

\section{East Facing Burn}

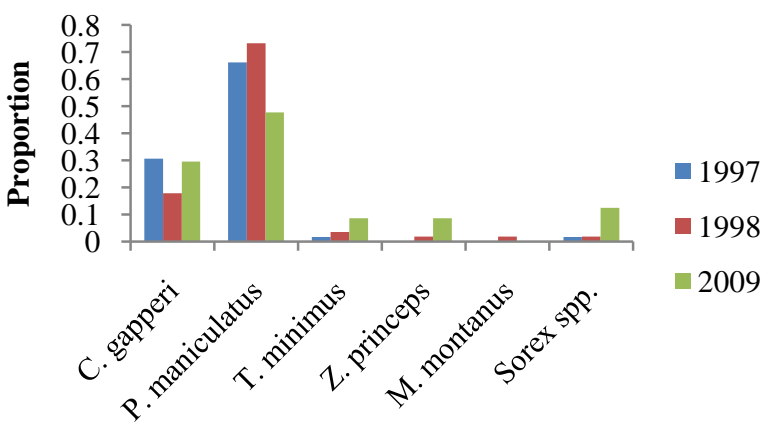

Figure 4. Number of individuals per species for 1997, 1998, and 2009 for the east facing burn.

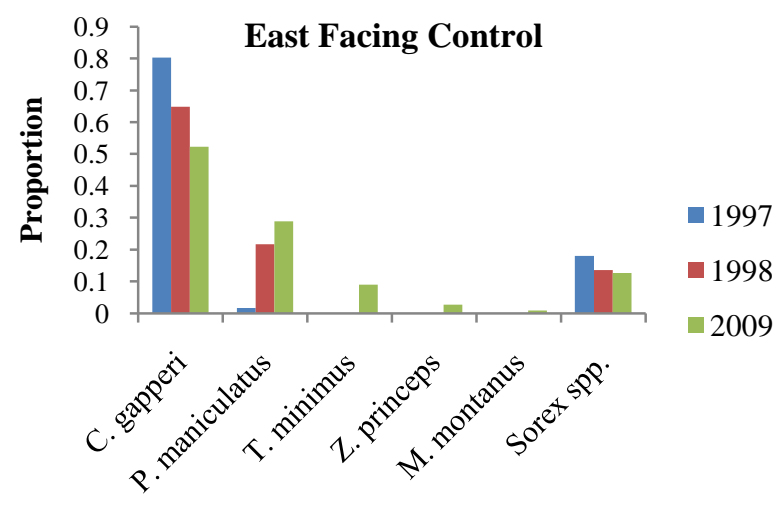

Figure 5. Number of individuals per species for 1997, 1998, and 2009 for the east facing control.

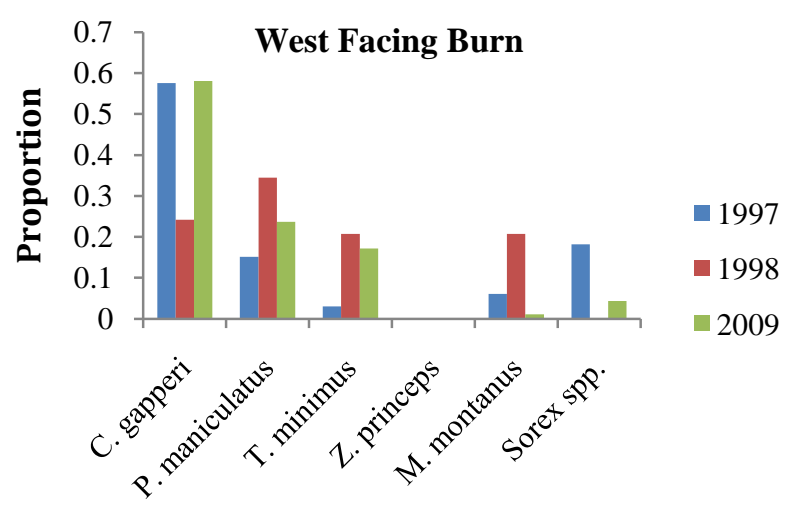

Figure 6. Number of individuals per species for 1997, 1998, and 2009 for the west facing burn. Note the fluctuation of Clethrionomys gapperi among the 3 studies. Compared to the east facing burn, Peromyscus maniculatus does not dominate the community.

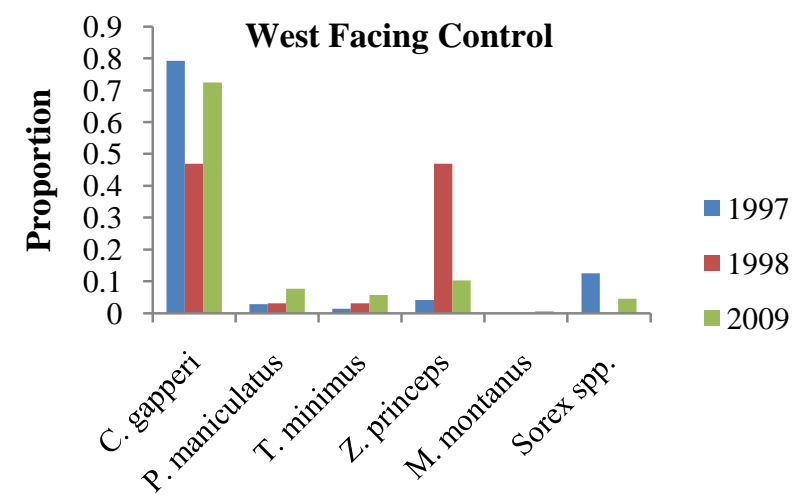

Figure 7. Number of individuals per species for 1997, 1998, and 2009 for the west facing control.

Table 3 includes total numbers (by grid and for all years) for the two most common species $(P$. maniculatus and $C$. gapperi). Given equal effort in trapping, direct comparisons of total numbers are feasible, but there is a wide range of total captures from year to year. Patterns, if present, are difficult to detect. There is also a large fluctuation in numbers between years (for example, the voles in EFC). Some grids exhibit interesting trends (for example, the decrease in deer mice in recent studies versus those done immediately following the fire).

Figure 8 illustrates changes in ShannonWiener diversity indices for the 4 grids for all studies since 1991. Immediately following the fires, the small mammal communities at the burn and control grids differ for both the west and east facing grids. 
Over time, the diversity (as measured by the indices) for burned and control grids for small mammal communities converge for the respective e/w slope.

Table 3. Total numbers of red backed voles and deer mice trapped on each grid for all years.

$\begin{array}{ccccccc}\begin{array}{cccc}\text { Clethrionomys } \\ \text { gapperi }\end{array} & & \begin{array}{c}\text { East } \\ \text { Facing }\end{array} & \begin{array}{c}\text { East } \\ \text { Facing } \\ \text { Burn }\end{array} & \begin{array}{c}\text { West } \\ \text { Facing }\end{array} & \begin{array}{c}\text { West } \\ \text { Facing } \\ \text { Control }\end{array} & \begin{array}{c}\text { Total } \\ \text { for } \\ \text { year }\end{array} \\ & 1990 & 5 & 46 & 3 & 48 & 102 \\ & 1991 & 21 & 81 & 40 & 110 & 252 \\ & 1997 & 19 & 49 & 19 & 57 & 144 \\ & 1998 & 10 & 24 & 7 & 15 & 56 \\ & 2009 & 31 & 58 & 54 & 113 & 256 \\ \text { Peromyscus } & & \text { East } & \text { East } & \text { West } & \text { West } & \\ \text { maniculatus } & & \text { Facing } & \text { Facing } & \text { Facing } & \text { Facing } & \\ & 1990 & \text { Burn } & \text { Control } & \text { Burn } & \text { Control } & \\ & 1991 & 140 & 21 & 55 & 4 & 160 \\ & 1997 & 41 & 1 & 53 & 19 & 268 \\ & 1998 & 41 & 8 & 10 & 1 & 60 \\ & 2009 & 50 & 32 & 22 & 12 & 116\end{array}$

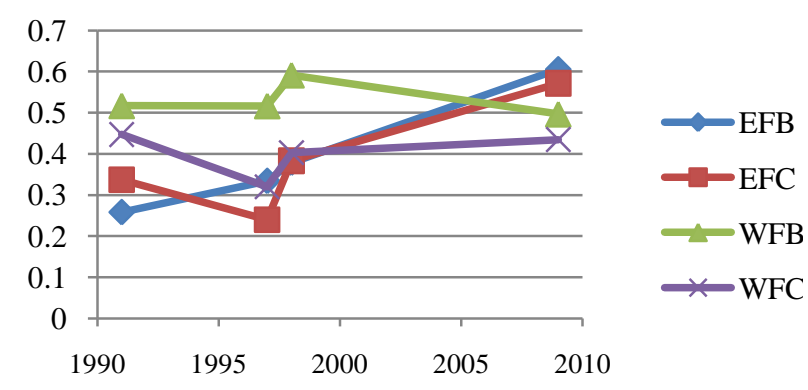

Figure 8. Values of Shannon Diversity Indices for the small mammal communities among the four grids over time since the first studies in the early 1990s. Abbreviations for grids are provided in Table 1.

\section{$\uparrow \quad$ DISCUSSION}

Other investigations conducted in Yellowstone and Grand Teton National Parks and nearby forests have provided data on the composition of small mammal communities post-fire. Barmore, Taylor, and Hayden (1976) trapped small mammals in Grand Teton National Park (GTNP) immediately after the Waterfalls Canyon fire in 1974 and reported that burned sites had higher densities of deer mouse and yellow-pine chipmunk (Tamias amoenus) than control on burn and control grids. Wood (1981) studied two burned (1974 and 1976) and two adjacent unburned spruce/fir/lodgepole forests in YNP in 1978 and 1979 and reported three abundant species: the southern red-backed vole, the deer mouse, and the yellow-pine chipmunk. Trap success was higher in unburned forests for the former and higher in the burns for the latter two, although the red-backed vole was the most abundant species in both burned and unburned sites. Finally, Zwolak and Foresman (2007) investigated the response of small mammals for two consecutive years following a forest fire in Montana. They reported an abundance of deer mice and reduced numbers of red backed voles and shrews as compared to unburned sites.

Results from the 1997-98 studies at Huckleberry Mountain for short term responses are somewhat consistent with other similar studies. The deer mouse dominated the east facing burn grid ie immediate years following fires (Figure 4), but not the west facing burn. The red backed vole was more common in non-burned grids than the deer mouse. However, red back vole numbers did fluctuate, especially in the west facing burn (Figure 6) and in this grid, unlike the east facing burn, the deer mouse did not dominate. However, in the undisturbed sites, numbers of deer mice were relatively lower than red backed voles. The red backed vole clearly dominated mature habitats. These results are consistent with the summary of conflicting results for the vole provided by Fisher and Wilkinson (2005). However, very small sample sizes in 1997-1998 (relative to other investigations) make any final conclusions tentative until abundance estimates are considered (see below).

Less is known regarding small mammal responses in the establishment stage (Lee, 2002) 1125 years post fire in boreal forests. The same species are often present, but relative abundances differ. Roy, Stelfox, and Nolan (1995) showed that red backed voles and masked shrews were common, but still less abundant than in old growth stands. Other species such as meadow voles and meadow jumping mice were uncommon or absent, presumably from habitat changes and limited food resources. Deer mice, though still common, were at a lower relative abundance than earlier years.

Results from 2009 are fairly consistent with previous findings. The same species are present among the grids 10-11 years later (21 years post fire), though proportions within the community are different than in previous years. Red backed voles are more common in control versus burned sites, though differences between them are less than in previous years. For the east facing grids, proportions of red backed voles are greater in control versus burned sites, similar to the results of Roy et al. (1995). However, again the west facing burn has an unexpectedly high proportion of red backed voles, similar to the results in 1997. Reasons for such an unusually large number of voles is unclear, but 
proportions may be misleading, especially from small sample sizes in 1997 (Table 3). Ideally, estimates of population abundance from 2009 may help to clarify potentially misleading proportional data and such estimates can be compared to previous years (Seville et al. 1997). Unfortunately abundance estimates (also sensitive to sample size) for the two dominant species ( $P$. maniculatus and $C$. gapperi) have not been calculated for 2009 primarily because of violated assumptions for the required model (Mt) utilized in the program CAPTURE. A large number of trap mortalities due to inclement weather raises concerns over the "capture-recapture" nature of abundance estimators. Models that can employ "removal" data will be applied and estimates from previous years will be recalculated with the same models for comparative purposes. Such analyses and results will be finalized following the 2010 field season. Until then, any conclusions must be viewed as tentative. None the less, it is clear that the same species are present, but their relative proportions are changing. In the burn grids, the less common species (e.g., Tamias minimus, Zapus princeps) are becoming more common as habitat recovers.

To our knowledge there have been no published investigations of long-term responses of shrews to fire in the Rocky Mountain region. Shrews known to occur in northwestern Wyoming include the dusky shrew (Sorex monticulus), dwarf shrew $(S$. nanus), masked shrew (S. cinereus), Merriam's shrew (S. merriami), and water shrew (S. palustris) (Clark 1973, Clark and Stromberg 1987, Spildie 1994). We collected 37 shrews and at least three species among the 4 grids (Table 1). Species breakdowns are not available from some of the previous studies, but such data are available from 1994 and 1997. Spildie (1994) reported that $90 \%(\mathrm{~N}=40)$ of shrews captured in pitfall or live-traps at the Huckleberry Mountain study site were masked shrews In 1997, the research team captured 49 shrews representing three species: $S$. monticolus, $S$. cinereus, and S. nanus. We did not capture $S$. nanus, but did recover $S$. merriami, the first time this species has been seen on any grid. Shrew species richness is increasing over time. Also, in at least one case, proportions of shrews (when lumped into a Sorex category) is increasing over time in the east facing burn, but such a pattern is not evident in the west facing burn. Whether this discrepancy is because of sampling error or microhabitat structure remains to be determined.

The changes in small mammal communities from the initiation to the establishment stages noted above naturally correspond to changes in the structure of the habitat. As Fisher and Wilkinson
(2005) note, "small mammal abundance increases with stand age after fire, in a manner that corresponds with species-specific habitat association." Though abundance estimates are forthcoming, and relationships between small mammals and the microhabitat structure will not be formally analyzed until after the 2010 field season, the habitats between burned and control grids are different based on data collected during the summer of 2009. Grasses provide greater coverage in the burned sites than in control sites, and herbaceous cover is less. However, some features, such as litter, are quite similar regardless of grid. Trees are still rare on the burned grids, but sapling density is high relative to control sites. How do these structural features relate to community structure? It will be very interesting to see if any relationships are uncovered. However, even in the absence of formal analyses, it is apparent that sufficient cover (leaf litter) is supporting diverse populations of shrews, and that low grass cover and high herbaceous cover are affiliated with large numbers of red backed voles.

\section{$\uparrow \quad$ FUTURE WORK}

We will return to Huckleberry Mountain in the summer of 2010 and continue the long-term study of the responses/structure of the small mammal communities following the 1988 fires. As has been done in previous years, location and protocol will be identical. Following the trapping sessions, a thorough comparison of all study years (where complete data are available) will track changes in small mammals and associated habitat structure. Additionally, analyses will be performed to characterize the habitat change and structure to better understand the effect habitat structure has upon structuring small mammal communities.

\section{$\downarrow$ ACKNOWLEDGEMENTS}

We wish to express our deepest appreciation to the following organizations and individuals for their support for and assistance with this research project: the UWNPS and UW Wyoming INBRE programs for financial support, Hank Harlow and staff for housing us at the AMK Ranch, Celeste Havener for all of her logistical support, Grand Teton National Park and Wyoming Game and Fish for providing permits to conduct the research, and Kelly Keenan, Stephanie Marker, Laura Cammileri, Amy Jacobs, and Matt Brown for their invaluable assistance in the field. 


\section{LITERATURE CITED}

Barmore WJ, Taylor D, Hayden P. 1976. Ecological effects and biotic succession following the 1973 Waterfalls Canyon fire in Grand Teton National Park. Unpublished research project report, Grand Teton National Park, Wyoming.

Clark TW. 1973. Distribution and reproduction of shrews in Grand Teton National Park. Northwest Science 47:128-131.

Clark TW, Stromberg MR. 1987. Mammals in Wyoming. Lawrence (KS): University of Kansas Press.

Fisher JT, Wilkinson L, 2005. The response of mammals to forest fire and timber harvest in the North American boreal forest. Mammal Review 35:51-81.

Kirkland GL Jr., Parmenter RR. 1997. A five-species assemblage of shrews from the sagebrushsteppe of Wyoming. Journal of Mammalogy, 78:83-89.

Lee P. 2002. Stages of forest succession. In: Song S, editor. The Ecological Basis for Stand Management Alberta, Vegreville (AB): Alberta Research Council.p. 3.1-3.3

Roy L, Stelfox JD, Nolan JW. 1995. Relationships between mammal biodiversity and stand age and structure in aspen mixedwood forests in Alberta. In: Stelfox JB, editor. Relationships Between Stand Age, Stand
Structure, and Biodiversity in Aspen Mixedwood Forests in Alberta. Edmonton (AB): Jointly published by Alberta Environment Center (AECV95-R1), Vegreville, AB and Canadian Forest Service (Project No 00014).p.159-189.

Seville RS, Spildie D, Stanton NL. 1998. Long term responses of small mammal communities to the 1998 Huckleberry Mountain Fire. Laramie (WY): UW/NPS Annual Report.

Spildie DR. 1994. The density and distribution of small mammals in Grand Teton National Park, Wyoming. Unpublished (Master's thesis). Laramie (WY): University of Wyoming.

Stanton NL, Buskirk SW, Spildie DR, Miller SL. 1991. Habitat distributions of small mammal communities in Grand Teton National Park. Laramie (WY): UW/NPS $15^{\text {th }}$ Annual Report.

Taylor DL. 1973. Some ecological implications of forest fire in Yellowstone National Park, Wyoming. Ecology 54:1394-1396.

Wood MA. 1981. Small mammal communities after two recent fires in Yellowstone National Park. Unpublished (Master's. thesis) Bozeman (MT):Montana State University.

Zwolak R, Foresman KR. 2007. Effects of a standreplacing fire on small mammal communities in montane forest. Canadian Journal of Zoology 85:815-822. 